\title{
Etidronate-Cytarabine Conjugate MBC-11
}

National Cancer Institute

\section{Source}

National Cancer Institute. Etidronate-Cytarabine Conjugate MBC-11. NCI Thesaurus.

Code C125901.

A synthetic conjug ate composed of the bisphosphonate etidronate linked to the cytostatic agent and antimetabolite cytarabine, with potential antineoplastic and antiresorptive activities. Upon intravenous administration of the etidronate-cytarabine conjug ate $\mathrm{MBC}-11$, the etidronate moiety targets bone and the two moieties are released upon hydrolysis. Etidronate binds to hydroxyapatite crystals in bone tissues and prevents its resorption. This prevents bone destruction and induces bone cell mineralization. In addition, the bone-targeting nature of this agent allows for the accumulation of cytarabine in bone tissue, where it is able to exert its antitumor effect locally by competing with cytidine for incorporation into DNA, thereby inhibiting DNA synthesis, while reducing systemic exposure. This leads to a destruction of boneassociated tumor cells, an inhibition of tumor cell proliferation and bone metastasis, and prevents tumor-mediated bone destruction. 